\title{
Faecal Blending for Nutrient Enrichment and Speedy Sanitisation for Soil Fertility Improvement
}

\author{
F. Ogwang, ${ }^{1}$ J. S. Tenywa, ${ }^{1}$ E. Otabbong, ${ }^{2}$ J. B. Tumuhairwe, ${ }^{1}$ and A. Amoding-Katusabe ${ }^{1}$ \\ ${ }^{1}$ Department of Agricultural Production, Makerere University, P.O. Box 7062, Kampala, Uganda \\ ${ }^{2}$ Department of Soil and Environment, Swedish University of Agricultural Sciences (SLU), P.O. Box 7014, 75007 Uppsala, Sweden
}

Correspondence should be addressed to J. S. Tenywa, jstenywa@agric.mak.ac.ug

Received 30 December 2011; Accepted 6 February 2012

Academic Editors: T. J. Cutright and J. A. Entry

Copyright (C) 2012 F. Ogwang et al. This is an open access article distributed under the Creative Commons Attribution License, which permits unrestricted use, distribution, and reproduction in any medium, provided the original work is properly cited.

\begin{abstract}
Human faeces have been used for soil fertility improvement over time, but limited information is available on the value of this resource in Africa. The fear of the pathogenicity of the material hinders the realisation of its potential value in agriculture. A study was conducted at Makerere University Agricultural Research Institute, Kabanyolo in Uganda, to investigate the sanitising potential and nutrient enrichment capabilities of animal wastes on human faeces from Ecological Sanitation (EcoSan) toilets. Treatments included EcoSan human faeces (EHF) blended with either poultry manure (PM) or cattle manure (CM) mixed in the ratios of $1: 1$ (dry weight basis), before the mixtures were composted. The layout consisted of fifteen wooden composting boxes of $1 \mathrm{~m}^{-3}$ dimensions, laid above ground. Each box was lined with $1.5 \mathrm{~m}^{3} 1000 \mathrm{um}$ polythene. Poultry manure and its blend with EHF enhanced high temperature and concentrations of plant nutrients. Human faeces alone had meagre nutrients concentrations, but high $\mathrm{K}^{+}$. The high $\mathrm{K}^{+}$was possibly due to inclusion of kitchen ash in the EcoSan toilets. Among the blended treatments, EHF + $\mathrm{PM}$ and $\mathrm{EHF}+\mathrm{CM}$ achieved 100 and 75\% sanitisation of E. coli and Enterococcus species, respectively.
\end{abstract}

\section{Introduction}

Increasing human faecal production causes environmental problems, especially in urban areas in developing countries. This is largely due to the rapid surge in human population arising from the more recent rural-urban migration phenomenon, coupled with ineffective birth control programmes. Unfortunately, the available sanitation facilities often fail to cope with the population growth rates. Thus, use of the less hygienic pit latrines is the most common. The situation is even more complicated by the intense settlements in wetlands where safe pit latrine use is restricted by water tables located within the required vertical depths. Unrestricted construction under such circumstances would open up interfaces between biologically contaminated faecal materials and natural water supply systems, with the eventual spread of water bone diseases to the same communities who lack access to safe water [1]. As such, toilets codenamed "ecological sanitation (EcoSan) toilets," were initiated over a century ago in several countries [2]. One of the most common such toilets comprises of a plastic tank divided into two parts, one for solid faecal material and the other for urine. Unfortunately, whereas urine has attracted great demand as a fertiliser and pesticide material among agricultural communities, the solid part still remains a disposal and environmental burden [3].

The immediate beneficial option for disposal of the faeces would be through use as a soil fertility amendment. Faecal materials have been utilised as soil productivity amendments for many generations, for instance, in China as night soil [4]. Unfortunately, such attempts have not taken root in Africa where soil fertility decline is colossal and yet faecal materials are invariably resented. Indeed, there are valid reasons for the disinterest since the stuff, when unsanitised, is unhygienic for use for any purpose and has been responsible for transmission of diseases in Africa. Even the EcoSan toilet materials which are mixed with various quantities of wood ash for drying, and yet left in situ to decompose for about six months after filling, for sanitisation Ecological Sanitation [2] are suspected to be pathogenically active [5]. The materials also contain wood ash in variable quantities that could affect the amount of organic carbon in the facility biologically and chemically to the extent that biodecomposition could be subsequently affected. Therefore, further sanitisation 
TAвLE 1: Chemical status of the EcoSan-faeces-based composting substrates.

\begin{tabular}{|c|c|c|c|c|c|c|c|c|c|}
\hline \multirow[b]{2}{*}{ Treatments } & \multicolumn{3}{|c|}{ Day 1} & \multicolumn{3}{|c|}{ Day 45} & \multicolumn{3}{|c|}{ Day 90} \\
\hline & Tot-K & Tot-Ca & Tot-P & Tot-K & Tot-Ca & Tot-P & Tot-K & Tot-Ca & Tot-P \\
\hline EHF & 3.7 & 7.4 & 0.6 & 3.4 & 7.4 & 0.3 & 3.1 & 6.5 & 0.6 \\
\hline $\mathrm{EHF}+\mathrm{CM}$ & 4.6 & 10 & 0.6 & 4.0 & 7.5 & 0.4 & 3.2 & 7.6 & 0.7 \\
\hline $\mathrm{EHF}+\mathrm{PM}$ & 2.9 & 7.4 & 0.8 & 3.9 & 7.2 & 0.4 & 2.9 & 5.9 & 0.7 \\
\hline $\mathrm{CM}$ & 1.4 & 1.3 & 0.5 & 2.0 & 1.2 & 0.4 & 1.5 & 0.9 & 0.9 \\
\hline $\mathrm{PM}$ & 1.1 & 0.7 & 0.9 & 1.8 & 0.9 & 0.4 & 3.0 & 1.0 & 1.1 \\
\hline $\mathrm{LSD}_{0.05}$ & 0.803 & 0.872 & 0.125 & & & & & & \\
\hline
\end{tabular}

EHF: human faeces; PM: poultry manure; CM: cattle manure; EHF + PM: human faeces + poultry manure; HF + CM: human faeces + cattle manure; Tot-K: total potassium, Tot-Ca: total calcium, Tot-P: total phosphorus.

TABLE 2: Carbon to nitrogen ratios for the blended and nonblended faecal materials during composting.

\begin{tabular}{lcccccc}
\hline & & \multicolumn{2}{c}{ Treatment } & & PM & \\
Day & EHF & EHF + CM & EHF + PM & CM & 69 & 13 \\
\hline 1 & 18 & 21 & 18 & 20 & 13 & 8.139 \\
45 & 22 & 12 & 13 & 23 & 10 & \\
90 & 16 & 11 & 11 & & 13 \\
\hline
\end{tabular}

EHF: human faeces; PM: poultry litter; CM: cattle manure; EHF + PM: human faeces + poultry manure; HF + CM: human faeces + cattle manure.

through composting might require elevation of the carbon levels for the compositing process to be able to generate the scale of heat energy needed to eliminate the microbes. Blending with other domestic wastes could effectively boost the $\mathrm{C}$ levels as well as enrich nutrient profiles of the EcoSan faecal materials for further effective sanitisation. Current household resources in Africa include cattle manure (which is often a mixture of faecal material and urine) and poultry mature, also whose composition varies greatly depending on bedding materials, nature of feed, and feed wastage.

The objective of this study was to evaluate the effectiveness of blending EcoSan faecal material with cattle or poultry manure on enhancing composting conditions for sanitisation and nutrient enrichment of the compost product.

\section{Materials and Methods}

This study was conducted twice in the fields of the Makerere University Agricultural Research Institute, Kabanyolo (MUARIK) in central Uganda. The Institute is located at $32^{\circ} 37^{\prime}$ East and $0^{\circ} 28^{\prime}$, at approximately $1,200 \mathrm{~m}$ above sea level [6]. The rainfall pattern is bimodal rainfall with a mean value of $1,250 \mathrm{~mm}$. Mean maximum temperatures vary from $28.5^{\circ} \mathrm{C}$ in January to $26.0^{\circ} \mathrm{C}$ in July, and minimum temperatures, $17.4^{\circ} \mathrm{C}$ in April to $15.9^{\circ} \mathrm{C}$ in July and August.

2.1. Treatments and Design. Treatment materials included EcoSan faecal material, cattle manure, and poultry manure. These included (i) EcoSan faecal material (EFM), (ii) sole poultry manure (PM), (iii) sole cattle manure (CM), (iv) blended EFM + PM, and (v) blended EFM + CM. The treatments were laid out in a completely randomised design, replicated three times. The treatment materials were composted in locally fabricated above-ground wooden boxes of $1 \mathrm{~m} \times 1 \mathrm{~m} \times 1 \mathrm{~m}$, constructed using soft wood planks. The boxes were perforated with three sets of holes on each side, to permit in situ air circulation and to eliminate the need for periodic turning as is done in pits. Each hole was fitted with a PVC pipe of $3.81 \mathrm{~cm}$ diameter, and $1.2 \mathrm{~m}$ long to permit in situ air circulation within the composting materials. Each of the pipes was also perforated with between 25 and 30 holes of about $1.5 \mathrm{~cm}$ in diameter. Each box was fitted with a perforated $1.5 \mathrm{~m}^{2}$ polyethylene sheet of $1000 \mathrm{um}$ gauge, to minimise nutrient leaching. The contents of the boxes were further covered with the polythene on top to prevent excess interference with rain water.

2.2. Source and Quality of Study Materials. The faecal materials were obtained from Kamwokya EcoSan toilets located in the low-income slum settlements of Kampala City located at latitude $0^{\circ} 19 \mathrm{~N}$ and longitude $32^{\circ} 25 \mathrm{E}$. The toilets, the tanks of which were made of metallic material, had been closed from use by the City Council authorities for about six months. (The metallic toilet materials discharge some elements, which can either be essential or can be toxic to plants.) Only the faecal chambers of the toilets were emptied for this purpose. The faecal stuff was securely packed in polythene-lined gunny bags to prevent leakage in the environment. The chemical and microbial profiles of the stuff are presented in Tables 1 and 4, respectively.

Cattle manure was obtained from the MUARIK dairy herd, which depended largely on out grazing on natural vegetation. The manure had been in an open air heap for at least four weeks; hence, it had inevitably undergone some level of decomposition and nutrient leaching. Its prestudy chemical and microbial status is presented in Tables 1 and 4. Poultry manure was also provided by the MUARIK layers poultry section, in the form of bedding materials. The material consisted of wood chippings and chicken droppings. 
TABLE 3: Change in $\mathrm{pH}$ among treatments with days of composting.

\begin{tabular}{lccccc}
\hline & & \multicolumn{2}{c}{ Treatments } \\
Day & EHF & EHF + CM & EHF + PM & CM & 8.2 \\
\hline 1 & 10.1 & 9.7 & 9.5 & 8.5 \\
45 & 10 & 9.7 & 9.4 & 8.3 \\
90 & 10 & 7.7 & 9.5 & 8.3 & 7.5 \\
\hline
\end{tabular}

HF: human faeces; PM: poultry manure; CM: cattle manure; HF + PM: human faeces + poultry litter; HF + CM: human faeces + cattle manure.

TABLE 4: Enterococci and E. coli counts (cfu/g) in the study substrates during composting.

\begin{tabular}{|c|c|c|c|}
\hline & \multicolumn{3}{|c|}{ Treatments } \\
\hline Days & EHF & $\mathrm{EHF}+\mathrm{CM}$ & $\mathrm{EHF}+\mathrm{PM}$ \\
\hline \multicolumn{4}{|c|}{ Enterococcus } \\
\hline 1 & $2 \times 10^{2}$ & Not detected & $\begin{array}{c}\text { Not } \\
\text { detected }\end{array}$ \\
\hline 90 & $1 \times 10^{2}$ & Not detected & $\begin{array}{c}\text { Not } \\
\text { detected }\end{array}$ \\
\hline \multicolumn{4}{|c|}{ Escherichia coli } \\
\hline 1 & Not detected & Not detected & $\begin{array}{c}\text { Not } \\
\text { detected }\end{array}$ \\
\hline 90 & $6.65 \times 10^{4}$ & $6.0 \times 10^{5}$ & $\begin{array}{c}\text { Not } \\
\text { detected }\end{array}$ \\
\hline
\end{tabular}

EHF: Ecosan human faeces; EHF + PM: human faeces + poultry manure; EHF + CM: human faeces + cattle manure.

In addition, there was evidence of residual feeds in the litter, whose quantities could not be determined retrospectively.

2.3. Management and Analysis of the Materials. Up to slightly over $800 \mathrm{~kg}$ (fresh weight) of each material in sole or blend forms was deposited in the boxes previously labelled with the respective treatment identities. For the blended forms, the materials were thoroughly mixed manually using securely gloved hands. Before deposition of the materials into the boxes, their moisture content was determined gravimetrically on samples taken and subjected to oven drying at $70^{\circ} \mathrm{C}$ for $48 \mathrm{hrs}$, and a correction factor was developed for determining the equivalent mass of the material on fresh weight basis. Prior to covering the boxes with the polythene sheet, the contents of each box were sampled (approximately $200 \mathrm{~g}$ ) for dry weight determination, as well as nutrient and microbial composition analysis. Dry weight of the materials was determined gravimetrically using an oven set at $70^{\circ} \mathrm{C}$ for $48 \mathrm{hrs}$. The nutrient levels were determined using the procedures outlined by Anderson and Ingram [7].

2.4. Parameters Measured. Temperature readings were taken using steel probe thermometers of $15 \mathrm{~cm}$ length, mounted on different spots of the composting pile to obtain an average temperature. During the study ( 90 days 10 subsamples were collected from different positions within $0-50 \mathrm{~cm}$ depths of the composting pile and mixed through quarter sampling to obtain a composite sample of about $200 \mathrm{~g}$. The composite samples were taken from each box at 1, 45, and 90 days of the process. Samples for microbial examinations were then stored under refrigeration for 10 days at $4^{\circ} \mathrm{C}$ prior to analysis.

The samples were subjected to laboratory analyses of $\mathrm{pH}$, electrical conductivity, total concentrations of potassium (Tot- $\mathrm{K}^{+}$), calcium (Tot-Ca ${ }^{++}$), phosphorus (Tot-P), nitrogen (Tot-N), and organic carbon (TOC). Except for $\mathrm{pH}$ and $\mathrm{EC}$ which were measured in fresh samples in ratios of $1: 10$ (dry $\mathrm{w} / \mathrm{v}$ ) and subjected to 1 hour shaking on a mechanical shaker (Tiquia and Tam [8]), all the after mentioned parameters were analysed using dried samples following the procedures described by Anderson and Ingram [7].

The presence and abundance of Escherichia coli and Enterococcus, as proxies for perseverance of human pathogens, were examined following procedures described in the FAO Manual of Food Quality Control FAO [9].

2.5. Statistical Analysis. The data obtained were subjected to analysis of variance using GenStat software, Version 12. Significant treatment means were separated using Fisher's Protected Least Significant Differences at 5\% probability level.

\section{Results}

3.1. Temperature. The temperature varied greatly within the material combinations (Figure 1). Generally and as expected, the temperature increased in all substrates during composting, but it declined after 16 days and remained nearly constant until the end of the composting process. Poultry manure maintained the highest temperature overall in the period before 60 days. Temperatures for EHF + CM and EHF were low and remained relatively constant but converged with the rest after the 60th day. 


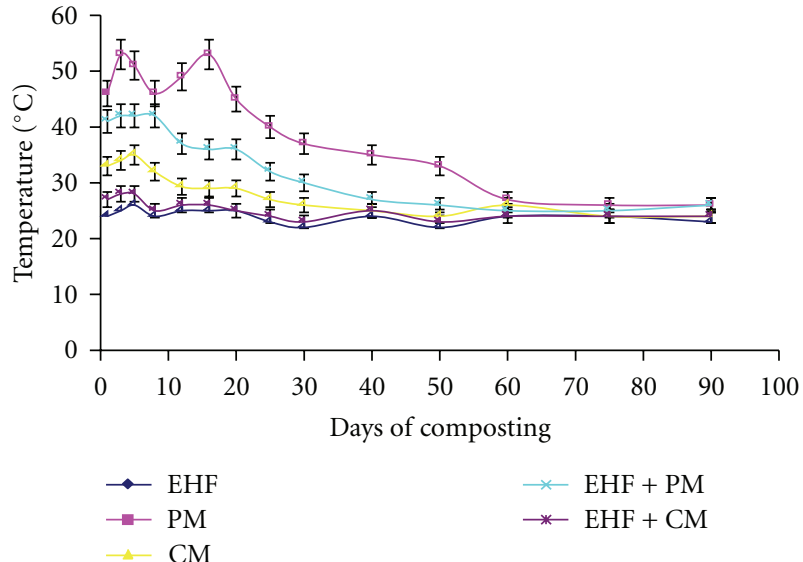

Figure 1: Temperature response patterns during composting of EcoSan-faeces based materials. EHF: human faeces; PM: poultry manure; CM: cattle manure; EHF + PM: human faeces + poultry manure; EHF + CM: human faeces + cattle manure.

\subsection{Potassium, Calcium, and Phosphorus Concentrations.} The concentration of $\mathrm{K}$ and $\mathrm{Ca}$ experienced both increases and decreases during composting (Table 1$)$. Total $\mathrm{K}$ concentration in PM increased $(P<0.05)$ from 1.1 to $3.0 \%$. The evidence of loss of $\mathrm{K}$ was more pronounced $(0.53 \%)$ $(P<0.05)$ in EHF + CM than in EHF. However, $\mathrm{K}$ concentrations in CM and EHF were significantly high and remained relatively constant over the composting period. In the case of calcium, substrates EHF + CM and EHF registered the highest concentrations progressively till the end of the study (Table 1). On the other hand, calcium values in PM and $\mathrm{CM}$ were significantly low $(P<0.05)$. Overall, poultry manure produced significantly highest $(P<0.05)$ total $P$ values and EHF, by contrast, produced lowest concentration among the substrates.

3.3. Total Nitrogen. Total nitrogen (Tot-N) concentrations in all substrates remained relatively stable (with the exception of CM (Figure 2). Poultry manure registered highest Tot$\mathrm{N}$, while EHF had the least value. The quantity of Tot-N, however, reduced by $11 \%$ from the value realised at the start of the study. By contrast, Tot- $\mathrm{N}$ in CM increased significantly $(P<0.05)$ by the last day of composting.

3.4. Total Organic Carbon (Tot-OC). All composting substrates, except HF, experienced significant Tot-C losses during composting (Figure 3 ). The losses were in the order of $45,39,33$, and $30 \%$, in substrates EHF + CM, EHF + $\mathrm{PM}, \mathrm{CM}$, and PM, respectively. Cattle manure was the richest in Tot-OC $(P<0.05) 58 \%$ right from the start of the study, while EHF was the poorest throughout the composting period.

3.5. Carbon to Nitrogen (C/N) Quotient. The $\mathrm{C} / \mathrm{N}$ (quotient) of $\mathrm{CM}$ was significantly higher than the control on day 1 compared to other substrates (Table 2). However by the 90th day, $\mathrm{C} / \mathrm{N}$ for all substrates had declined and values ranged

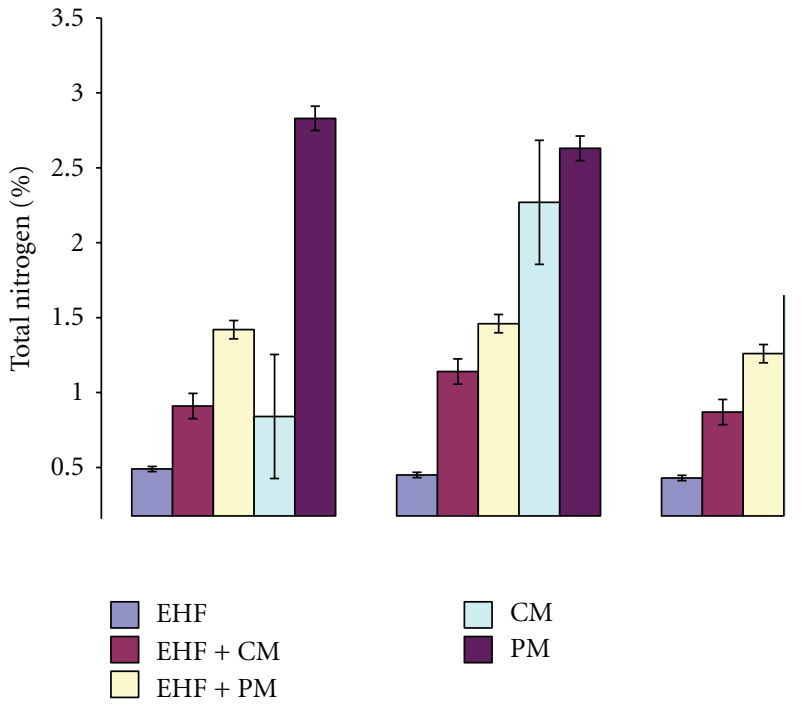

Figure 2: Total nitrogen content in composting EcoSan-faeces based materials. EHF: human faeces; PM: poultry manure; CM: cattle manure; EHF + PM: human faeces + poultry manure; EHF + CM: human faeces + cattle manure.

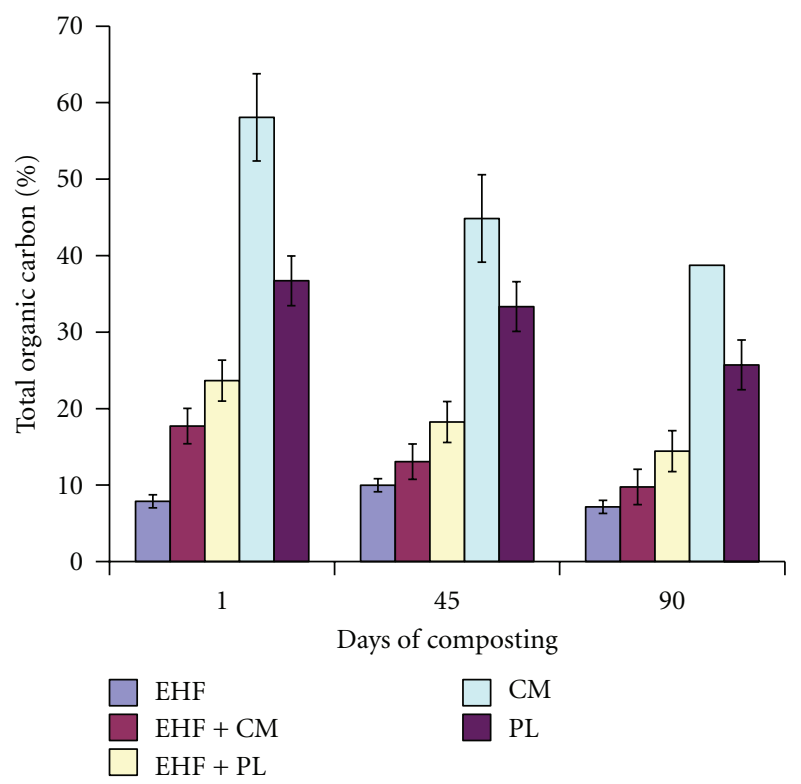

FIgUre 3: Total organic carbon content in EcoSan-feaces based materials during composting. EHF: human faeces; PM: poultry manure; CM: cattle manure; $\mathrm{EHF}+\mathrm{PM}$ : human faeces + poultry manure; EHF + CM: human faeces + cattle manure.

between 10 and 23. Ecosan human faecal material + cattle manure and sole CM experienced significant $(P \leq 0.05)$ reductions in their $\mathrm{C} / \mathrm{N}$ ratios by the 90th day.

3.6. $p H$. Data for the $\mathrm{pH}$ of the study materials during composting are presented in (Table 3 ). While the $\mathrm{pH}$ of $\mathrm{EHF}, \mathrm{CM}$, and $\mathrm{EHF}+\mathrm{PM}$ remained relatively stable during composting, that of substrates EHF + CM and PM reduced significantly by the 90 th day of composting. 


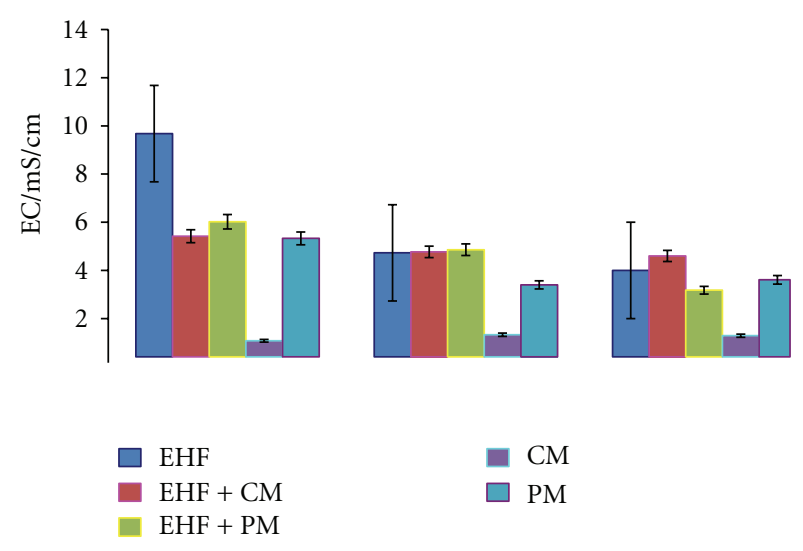

Figure 4: Changes in EC $\left(\mathrm{mScm}^{-1}\right)$ during composting of faeces based materials. HF: human faeces; PM: poultry manure; CM: cattle manure; EHF + PM: Ecosan human faeces + poultry manure; $\mathrm{EHF}+\mathrm{CM}$ : human faeces + cattle manure.

3.7. Electrical Conductivity. All composting substrates, except EHF, experienced steady decrease in electrical conductivity (EC) during composting (Figure 4). Substrates EHF, $\mathrm{EHF}+\mathrm{PM}$, and $\mathrm{PM}$ displayed significant $(P<0.05)$ drops in EC in the order of 59, 47, and $32 \%$, respectively, over the composting period. Cattle manure's value did not change significantly, yet EHF registered highest EC overall.

3.8. Enterococcus and Escherichia coli. Overall, the blended substrates were more successful in destroying the faecalbased microorganisms than their corresponding unmixed compost substrates counterparts (Table 4). The blended cases $(\mathrm{EHF}+\mathrm{CM}$ and $\mathrm{EHF}+\mathrm{PM})$ destroyed up to $87.5 \%$ of Enterococcus and E. coli. Overall, the EHF + PM blend was the only material that achieved $100 \%$ decimation of both parasites. The sole human faeces had the highest counts of Enterococcus and E. coli and achieved barely 25\% parasite destruction.

\section{Discussion}

The temperature response patterns by the different composting substrates depicted in (Figure 1) demonstrate typical biodecomposition processes in advanced stages [10]. This suggests that the decomposition process partly occurred in situ within the EcoSan toilets and in the CM and PM piles (Figure 1). However, the thermophilic temperature phase was reached shortly in poultry litter. This is in agreement with findings by Epstein [11] in which it was noted that in typical composting situations, temperature should be above $50^{\circ} \mathrm{C}$ in the first two weeks of the process. Most substrates experienced decreasing temperatures progressively after the thermophilic phase (Figure 1). This is a natural phenomenon because naturally temperature is expected to decrease due to diminution of microbial activity. Low temperature exhibited by faeces and EHF + CM throughout the composting period is possibly due to the low fibre and carbon content in this substrate combination [12]. Adequate carbon content is essential for microbial diversity and general physiological processes that are responsible for heat build-up [10]. From another standpoint, the limited presence of carbon in the composting faeces could have been caused by kitchen wood ash which was added to the faeces within the source toilets as a sanitising agent. This ash could have diluted the carbon in the HF, hence leading to reduced respiration activities [13].

The increase in total potassium (Tot-K) in the poultry manure (Table 1 ) is normal because $\mathrm{K}$ is not often lost during composting except in cases of leaching [14]. The reduction, in biomass of the composting materials due to $\mathrm{CO}_{2}$ evolution tends to favour the concentration of nonaffected substances such as K. Indeed, this increase in Tot-K corresponded with loss of Tot-OC (Figure 3). On the other hand, the decrease in Tot-K in EHF and EHF + CM composting materials (Table 1) could have been due to leaching since the composting structures were not maintained totally leak proof. It is also possible that in these materials, tot- $K$ could have been quickly solubilised and leached out, compared to the PM which first has to be broken down before release of tot-K. Considering that $\mathrm{K}$ is not a plant structural element unlike $\mathrm{N}, \mathrm{P}$, and $\mathrm{S}$. Hence, it is freely released as soon as the integrity of plant cells is lost after death of the plants. Similar losses of $\mathrm{K}$ have been reported in previous studies $[15,16]$ and related explanations were advanced. From another standpoint, the low Tot-K in the composting CM could be attributed to losses of $\mathrm{K}$ due to uncontrolled rainfall effects in the open roof manure piles in the dairy section on the MUARIK farm. Furthermore, although Ca is largely a structural element in plants, its concentration also decreased in the composting CM and PM (Table 1) very likely for similar reasons as K. This trend in calcium reduction during composting was also observed by Tiquia et al. [14] while composting hoop manure. The significantly high total phosphorus (Tot-P) in poultry manure after composting (Table 1) could be because tot- $\mathrm{P}$ is not lost in the microbial respiration processes that constitute composting and that the available form of $\mathrm{P}$ is not volatile. Tot-P could have reacted with calcium to form an insoluble complex, calcium phosphate, a compound formed when phosphorus reacts with calcium. Studies by [17-19] also reported high tot- $\mathrm{P}$ values during in-vessel composting of household wastes.

The stable values of total nitrogen (Tot-N) in the composting materials throughout the study period (Figure 2) could be attributed to the advantageous effect of the airtube composting technology in conserving $\mathrm{N}$ in the system. Inefficient composting systems cause losses of $\mathrm{N}$ through volatilisation $[15,16]$. Furthermore, the high content of Tot$\mathrm{N}$ in poultry litter through the composting period (Figure 2) was evidence that this material was uniquely rich in $\mathrm{N}$ among the materials used in the study. This could be due to $\mathrm{N}$ rich poultry feeds that are often lost into the litter during inefficient feeding. In fact, the poultry litter was collected from a commercial poultry farm which emphasises quality feeds to achieve quality eggs and broilers to meet customer demands. Similar findings on poultry litter were reported by earlier studies which worked with high technology composting methods $[15,20,21]$. On the other hand, the relatively low Tot-N in EHF, compared to other substrates, 
could be attributed to volatilisation and leaching of $\mathrm{N}$ from source toilets, since this material had already spent nearly six months in the toilets before collection for the experiment.

The reduction in carbon in composting materials (Figure 3) is indeed the basic essence for this biodecomposition process which is intended to shrink the carbon to nitrogen ratio significantly to permit sufficient release of the latter to crops during mineralisation. On the other hand, the low levels of carbon in EHF could also be explained by high ash content in the EcoSan-sourced human faeces. This seems to explain why carbon richer substrates boosted the temperature levels (Figure 1). This is in agreement with [12] in which they demonstrated that human faeces with added ash were low in organic carbon content. Therefore, in order for farmers to benefit from the use of EcoSan faeces, there will be need for enriching the material with high carbon substrates such as poultry litter. Nevertheless, this aspect needs further investigation in order to reach conclusive evidence. In the present study, PM blend has performed the best in boosting temperature in the composters.

The high $\mathrm{C} / \mathrm{N}$ of $\mathrm{CM}$ right from the first day of composting is linked to its inherent low $\mathrm{N}$ initially (Table 2). The low Tot-N could have arisen from volatilisation and leaching within the open air decomposed piles in the kraal before collection for the experiment. Furthermore, the $\mathrm{C} / \mathrm{N}$ values registered at the end of composting meant that the materials had attained maturity and thus were suitable for use as organic fertilisers. According to [22], materials with $\mathrm{C} / \mathrm{N}$ ratios in the range of $>35<15$ are considered not suitable for use as composting substrates because at $\mathrm{C} / \mathrm{N}$ beyond 35 , the rate of composting is slowed down, while below 15 , there is loss of nitrogen through ammonia volatilisation. The $\mathrm{C} / \mathrm{N}$ at end of composting concurred with the ideal value of 25 recommended by several earlier workers [21, 23-25]. This, therefore, suggests that the materials in the present study were suitable for use as fertilisers, although there is still need to establish their agronomic effectiveness.

The significant reduction in $\mathrm{pH}$ in substrates $\mathrm{EHF}+\mathrm{PML}$ and PML could be attributed to release of organic acids, for example, uric acids during composting [11]. However, the reductions in $\mathrm{pH}$ values in $\mathrm{EHF}+\mathrm{CM}$ and $\mathrm{PML}$ substrates though significant were still within the acceptable range of pH 6 to 9 for good composts [26, 27].

The decrease in electrical conductivity (EC) of most substrates (Figure 4) could be attributed to precipitation of soluble salts (such as Ca to calcium phosphate) and the volatilisation of ammonia due to the generally high $\mathrm{pH}$ values resulting from the high ash material added to the faecal material (Table 3). Similar observation was made by [28] while working with coal fly ash as a composting material for sewerage sludge. The uniquely high EC value in HF is linked to the addition of significant quantities of ash in the EcoSan toilets. In fact, [13] estimated ash to be up to $77 \%$ of the overall faecal mass in the toilets in Uganda. Moreover, wood ash is typically known to be rich in bases which automatically render it alkaline. Indeed, historically, kitchen ash has been used as a liming material by various communities worldwide $[12,13]$. Thus, for human faeces to be used as ferilisers, the amount of ash to be added may need to be regulated so as not to alter the quality and quantity of other faecal components significantly that are vital for achieving a quality compost product.

The nondetection (100\% destruction) of Enterococcus and E. coli in the EHF + PM in the entire composting period (Table 4) likely arose from the salinity and dehydrating effect of the ash added to the faeces in the EcoSan toilets. In the ash, there are oxides and hydroxide ions and basic salts which cause a rise in $\mathrm{pH}$. This alkaline environment most likely created an osmotic concentration gradient, which dehydrated water from microbial cells. This outward movement of water could have led to effective desiccation and destruction of enteric microbial membranes [29-31], hence leading to the death of the microorganisms [32]. AK et al. [33] also conducted a study and found that Enterococcus and E. coli species of organisms cannot survive at $\mathrm{pH}<4.4$ and $>9$. Furthermore, the relatively high temperature attained $(>40$ $<45^{\circ} \mathrm{C}$ ) (Figure 2) in especially the EHF + PM during the first eight days of composting could have equally contributed to destruction of the enteric pathogens. Thus, it is evident that $\mathrm{HF}+\mathrm{PM}$ blend is the most suitable for use as an organic fertiliser for soil fertility management based on EcoSan materials, compared to the EHF + CM blend. On the contrary, the possible reason for the exponential rise of E. coli $\left(10^{4}\right.$ and $10^{5}$ ) in EHF and EHF + CM on day 90 could be associated with the presence of moisture in the pile, which provided a breeding ground hence causing re-growth of E. coli, [34, 35].

In conclusion, the best sanitation of EcoSan human faeces is achieved by blending the material with poultry manure and this is attained at a maximum temperature of $52^{\circ} \mathrm{C}$ and within 90 days of composting. Blending with PM or $\mathrm{CM}$ increases the nutrient quantity and quality of the EcoSan faeces, hence increasing its soil fertility improvement value. Kitchen ash, which is added to the EcoSan latrines to dry up the faeces and deodour the material, needs to be optimised quantitatively in order not to interfere with the composting processes.

\section{References}

[1] E. W. Kimani-Murage and A. M. Ngindu, "Quality of water the slum dwellers use: the case of a Kenyan slum," Journal of Urban Health, vol. 84, no. 6, pp. 829-838, 2007.

[2] A. Rosemarin, "Putting ecosan on the global agenda-results from the 3rd World Water Forum, Kyoto, March 16-23, 2003," in Proceedings of the 2nd International Symposium on Ecological Sanitation, incorporating the 1st IWA Specialist Group Conference on Sustainable Sanitation, Lubeck, Germany, April 2003.

[3] IPS AFRICA, "AGRICULTURE-UGANDA: Pee Solves a Problem," 2011, http://www.ips.org/africa/2010/10/agricultureuganda-pee-solves-a-problem/.

[4] Wikipedia, "Night soil," 2011, http://en.wikipedia.org/wiki/ Night_soil\#Sanitation_issues.

[5] A. Rosemarin, N. Ekare, I. Caldwell et al., Pathways for Sustainable Sanitation: Achieving the Millenium Development goals, IWA Publishing, London, UK, 2008.

[6] W. O. Odwongo, F. B. Bareeba, and J. S. Mugerwa, "The potential of Russian comfrey as a feedstuff in Uganda," in Proceedings of the 1st Uganda Pasture Network Workshop, E. N. Sabiiti and P. Henderlong, Eds., pp. 30-40, 1987. 
[7] J. M. Anderson and J. S. I. Ingram, Tropical Soil Biology and Fertility: A Handbook of Methods, CAB International, Wallingford, UK, 2nd edition, 1993.

[8] S. M. Tiquia and N. F. Y. Tam, "Characterization and composting of poultry litter in forced-aeration piles," Process Biochemistry, vol. 37, no. 8, pp. 869-880, 2002.

[9] FAO. Food and Agriculture Organisation of the United Nations, Manual of Food Quality Control: 4. Microbiology Analysis, Bucham Publishers, West Sussex, UK, 10th edition, 2001.

[10] Y. Eklind, C. Sundberg, S. Smårs et al., "Carbon turnover and ammonia emissions during composting of biowaste at different temperatures," Journal of Environmental Quality, vol. 36, no. 5, pp. 1512-1520, 2007.

[11] E. Epstein, The Science of Composting, Technomic Publishing Co., Lancaster, Pa, USA, 1997.

[12] B. Vinnerås, H. Jonsson, E. Salomon, and A. Stintzing, "Tentative Guidelines for Agricultural use of urine and faeces," in Proceedings of the 2nd International Symposium on Ecological Sanitation, pp. 101-107, April 2003.

[13] C. Niwagaba, M. Nalubega, B. Vinnerås, C. Sundberg, and H. Jönsson, "Bench-scale composting of source-separated human faeces for sanitation," Waste Management, vol. 29, no. 2, pp. 585-589, 2009.

[14] S. M. Tiquia, T. L. Richard, and M. S. Honeyman, "Carbon, nutrient, and mass loss during composting," Nutrient Cycling in Agroecosystems, vol. 62, no. 1, pp. 15-24, 2002.

[15] G. A. Ogunwande, J. A. Osunade, K. O. Adekalu, and L. A. O. Ogunjimi, "Nitrogen loss in chicken litter compost as affected by carbon to nitrogen ratio and turning frequency," Bioresource Technology, vol. 99, no. 16, pp. 7495-7503, 2008.

[16] J. B. Tumuhairwe, J. S. Tenywa, E. Otabbong, and S. Ledin, "Comparison of four low-technology composting methods for market crop wastes," Waste Management, vol. 29, no. 8, pp. 2274-2281, 2009.

[17] S. R. Iyengar and P. P. Bhave, "In-vessel composting of household wastes," Waste Management, vol. 26, no. 10, pp. 1070 1080, 2006.

[18] H.-S. Tai and W.-H. He, "A novel composting process for plant wastes in Taiwan military barracks," Resources, Conservation and Recycling, vol. 51, no. 2, pp. 408-417, 2007.

[19] J.-C. Tang, N. Maie, Y. Tada, and A. Katayama, "Characterization of the maturing process of cattle manure compost," Process Biochemistry, vol. 41, no. 2, pp. 380-389, 2006.

[20] M. P. Bernal, C. Paredes, M. A. Sánchez-Monedero, and J. Cegarra, "Maturity and stability parameters of composts prepared with a wide range of organic wastes," Bioresource Technology, vol. 63, no. 1, pp. 91-99, 1998.

[21] S. Goyal, S. K. Dhull, and K. K. Kapoor, "Chemical and biological changes during composting of different organic wastes and assessment of compost maturity," Bioresource Technology, vol. 96, no. 14, pp. 1584-1591, 2005.

[22] J. F. Parr, S. B. Hornick, and D. D. Kauffmann, "Use of microbial innoculants and organic fertilizers on Agricultural production," Food and Fertiliser Technology Centre, pp. 1-16, 1994.

[23] D. Hoornweg, T. Laura, and O. Lambert, Composting and its Applicability in Developing Countries, Working paper series 8, Urban Development Division the World Bank, Washington DC, USA, 1999.

[24] CPHEEO, Manual on Municipal Solid Waste Management, Central Public Health and Environmental Engineering Organisation, New Delhi, India, 2000.
[25] L. J. Brewer and D. M. Sullivan, "Maturity and stability evaluation of composted yard trimmings," Compost Science and Utilization, vol. 11, no. 2, pp. 96-112, 2003.

[26] R. T. Haug, The Practical Handbook of Compost Engineering, Lewis Publishers, Boca Raton, Fla, USA, 1993.

[27] C. Sundberg, S. Smårs, and H. Jönsson, "Low pH as an inhibiting factor in the transition from mesophilic to thermophilic phase in composting," Bioresource Technology, vol. 95, no. 2, pp. 145-150, 2004.

[28] J. W. C. Wong, G. W. Y. Li, and M. H. Wong, "Coal fly ash as a composting material for sewage sludge: effects on microbial activities," Environmental Technology, vol. 16, no. 6, pp. 527537, 1995.

[29] H. Heinonen-Tanski, E. M. Niskanen, P. Salmela, and E. Lanki, "Salmonella in animal slurry can be destroyed by aeration at temperatures," Journal of Applied Microbiology, vol. 85, no. 2, pp. 277-281, 1998.

[30] C. Moe and R. Izurieta, "Longitudinal study of double vault urine diverting toilets and solar toilets in El Salvador," in Proceedings of the 2nd International Symposium on Ecological Sanitation, Incorporating with the IWA Specialist Group Conference on Sustainable Sanitation, Lübeck, Germany, April 2004.

[31] L. M. Austin and T. E. Cloete, "Safety aspects of handling and using fecal material from urine-diversion toilets - a field investigation," Water Environment Research, vol. 80, no. 4, pp. 308-315, 2008.

[32] T. Redlinger, J. Graham, V. Corella-Barud, and R. Avitia, "Survival of fecal coliforms in dry-composting toilets," Applied and Environmental Microbiology, vol. 67, no. 9, pp. 4036-4040, 2001.

[33] N. O. Ak, D. O. Cliver, and C. W. Kaspar, "Cutting boards of plastic and wood contaminated experimentally with bacteria," Journal of Food Protection, vol. 57, no. 1, pp. 16-22, 1994.

[34] C. Schönning and T. A. Stenström, Guidelines for the safe use of urine and faeces in Ecological Sanitation systems, SEI, Stockholm, Sweden, 2004.

[35] WHO, Guidelines for the safe use of wastewater, excreta and greywater. Excreta and grey water use in agriculture, vol. 4, World Health Organisation, 2006. 

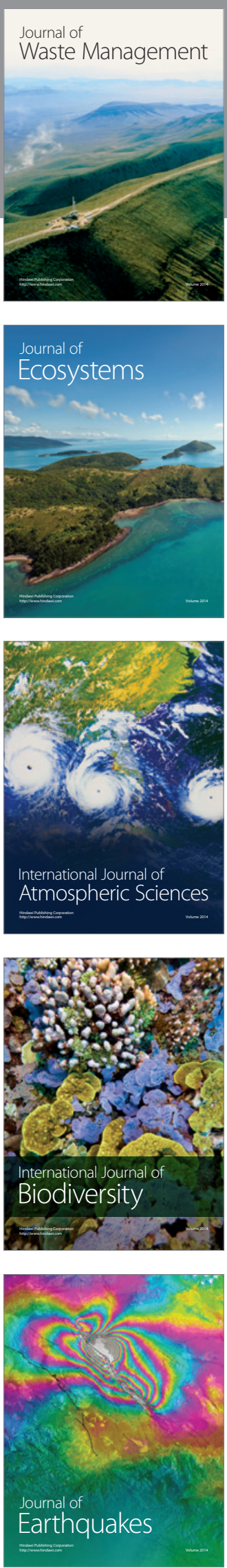
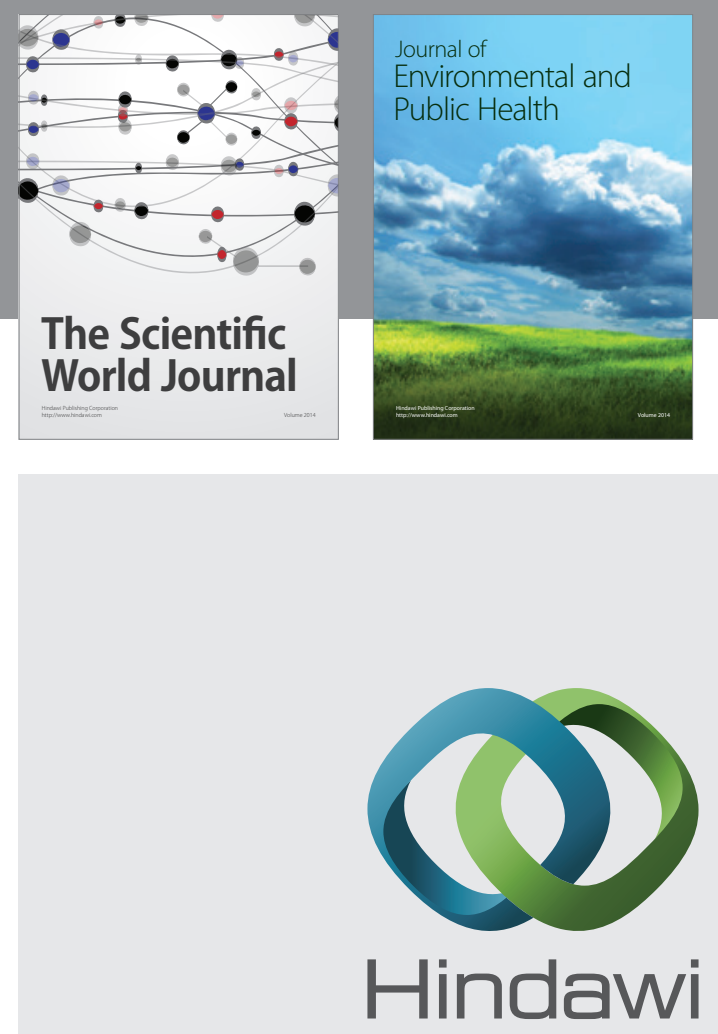

Submit your manuscripts at

http://www.hindawi.com
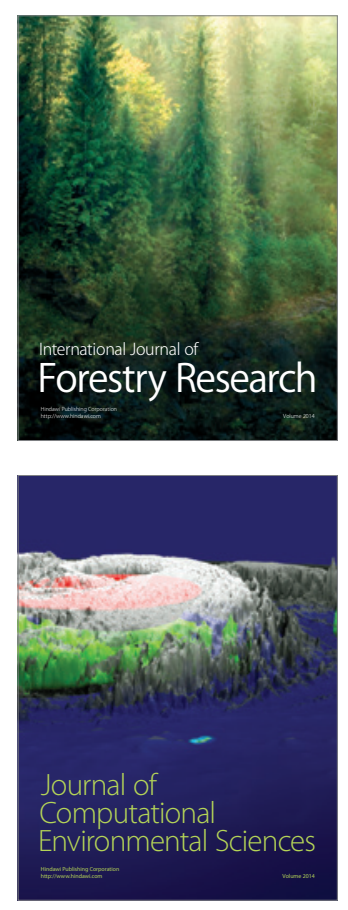
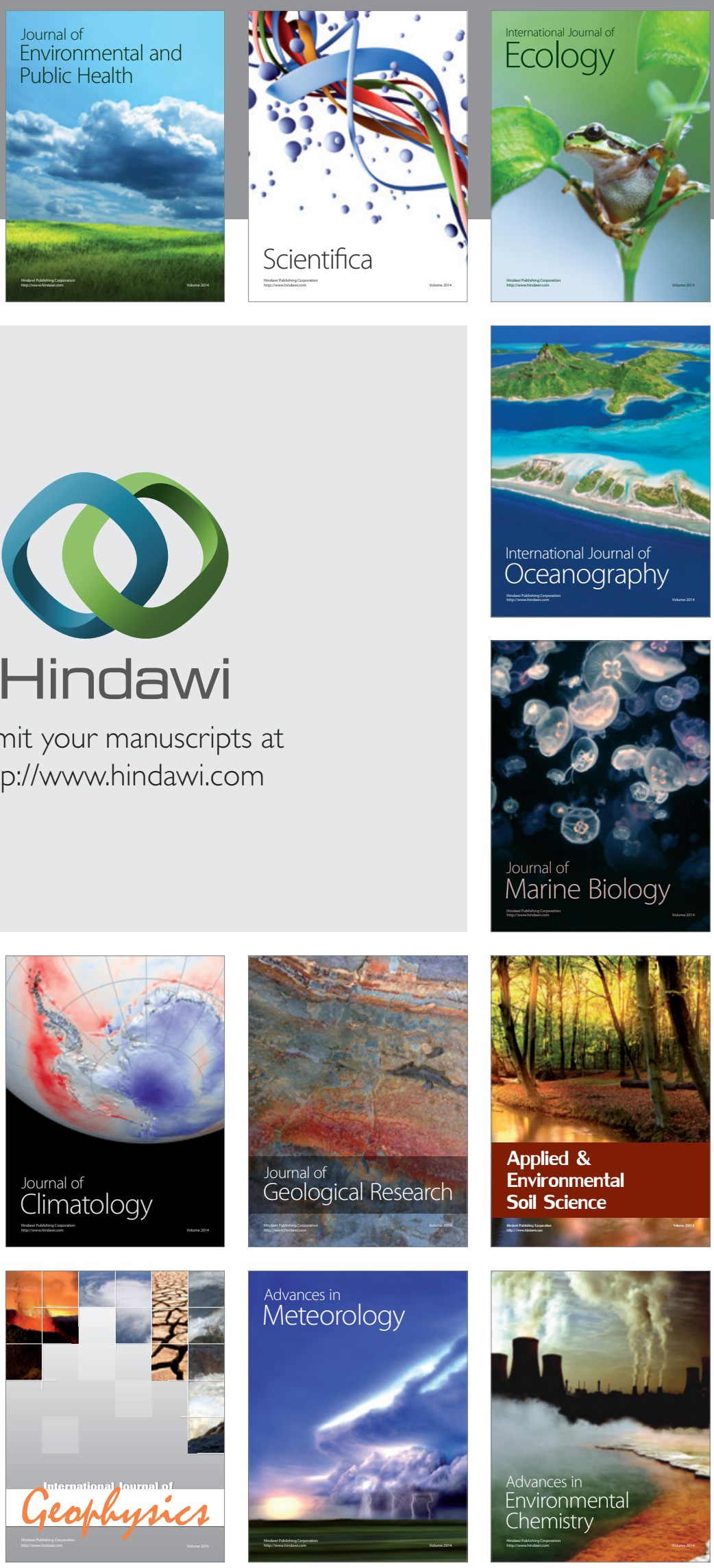